九州大学学術情報リポジトリ

Kyushu University Institutional Repository

\title{
Norepinephrine does not alter NPY and POMC mRNA expression in neonatal chicks
}

\section{Katayama, Sachiko}

Laboratory of Regulation in Metabolism and Behavior, Graduate School of Bioresource and Bioenvironmental Sciences, Kyushu University

\section{Tomonaga, Shozo}

Laboratory of Regulation in Metabolism and Behavior, Graduate School of Bioresource and Bioenvironmental Sciences, Kyushu University

\section{Sato, Momoka}

Laboratory of Regulation in Metabolism and Behavior, Graduate School of Bioresource and Bioenvironmental Sciences, Kyushu University

\section{Yamane, Haruka}

Laboratory of Regulation in Metabolism and Behavior, Graduate School of Bioresource and Bioenvironmental Sciences, Kyushu University

他

http://hdl. handle. net/2324/26591

出版情報: Comparative Biochemistry and Physiology Part A : Molecular \& Integrative Physiology. 156 (1), pp. 143-146, 2010-05-01. Elsevier

バージョン:

権利関係: (C) 2010 Elsevier Inc. 
CBP manuscript 17846 - Part A

\title{
Norepinephrine does not alter NPY and POMC mRNA expression in neonatal chicks
}

\author{
Sachiko Katayama, Shozo Tomonaga, Momoka Sato, Haruka Yamane, \\ Yousuke Tsuneyoshi, D. Michael Denbow ${ }^{1}$ and Mitsuhiro Furuse*
}

Laboratory of Regulation in Metabolism and Behavior, Graduate School of Bioresource and Bioenvironmental Sciences, Kyushu University Fukuoka 812-8581, Japan

${ }^{1}$ Department of Animal and Poultry Sciences, Virginia Polytechnic Institute and State University, Blacksburg, VA 24061-0306, USA

*Correspondence to: M. Furuse, PhD, Laboratory of Regulation in Metabolism and Behavior, Graduate School of Bioresources and Bioenvironmental Sciences, Kyushu University, Fukuoka 812-8581, Japan.

E-mail address: furuse @ brs.kyushu-u.ac.jp

Phone \& Fax: +81-92-642-2953

\begin{abstract}
Norepinephrine (NE), synthesized in both the central and peripheral nervous system, is involved in food intake regulation of both mammals and chickens. Neuropeptide $\mathrm{Y}$ (NPY), a potent orexigenic peptide, is co-localized with NE neurons in the central and peripheral nervous system, suggesting an interaction. Proopiomelanocortin (POMC) is the precursor of $\alpha$-melanocyte stimulating hormone, a potent anorexigenic peptide synthesized in the hypothalamus. In this study, two experiments were conducted to examine the effect of intracerebroventricular (ICV) injection of NE on appetite mediators in neonatal chicks. Experiment 1 was done to confirm the effect of centrally administered $\mathrm{NE}(0,25,50$, and $100 \mu \mathrm{g})$ on food intake following a $3 \mathrm{~h}$ fast, and to determine the change in NPY mRNA expression in the central nervous system (CNS).
\end{abstract}


In Experiment 2, chicks fed ad libitum were treated ICV with NE $(50 \mu \mathrm{g})$ to determine if changes occurred in brain NPY and POMC mRNA levels. In Experiment 1, the ICV injection of NE dose-dependently reduced food intake, but there was no change in NPY mRNA expression in the CNS. In Experiment 2, there was no significant change in NPY and POMC mRNA expression between the control and NE treated group, indicating that ICV injection of NE may not be associated with changes in NPY or POMC gene expression.

Key words : $\alpha$-melanocyte stimulating hormone, feeding behavior, neonatal chicks, neuropeptide Y, norepinephrine, proopiomelanocortin

\section{Introduction}

Feeding behavior is mainly regulated by the central nervous system (CNS). The regulation of this behavior is complex because it involves many factors including neurotransmitters, neuromodulators, and their interaction. Many researches were done for the regulation, but the majority is for mammals. The regulation of avian species is less elucidated.

Norepinephrine (NE)-containing neurons innervate the neocortex, thalamus, hypothalamus, hippocampus, and other brain regions of mammals (Wellman, 2000). Leibowitz (1977) showed that NE influenced appetite acting at adrenergic receptors in the rat paraventricular nucleus (PVN), ventromedial nucleus, and lateral hypothalamic area (LHA). In rodents, NE increased food intake when activating $\alpha_{2}$ adrenergic receptors (Leibowitz, 1988) and decreased food intake when activating $\alpha_{1}$ receptors (Morien et al., 1993). Similarly, NE influences feeding behavior in chickens depending on the brain region (Denbow et al., 1993) and receptors (Bungo et al., 1999). Low doses of the $\alpha_{2}$-adrenergic agonist clonidine stimulated feeding in chickens whereas higher doses inhibited feeding while simultaneously causing narcolespy (Bungo et al., 1999, 2001). In addition, extracellular NE within the hypothalamus increased during feeding (Tachibana et al., 2001).

Neuropeptide Y (NPY), a 36-amino acid peptide, was purified and sequenced by Tatemoto (1982 a, b), and is a member of the pancreatic polypeptide family which 
includes peptide YY and pancreatic polypeptide. NPY is one of the most potent stimulators of feeding behavior for both mammals (Kalra, 1997) and chickens (Kuenzel et al., 1987). It is synthesized mainly in the arcuate nucleus (ARC) (Bai et al., 1984), and is co-localized in the NE neurons in mammals (Everitt et al., 1984). In chickens, NPY mRNA is abundant in the infundibular nucleus (IN), the equivalent of the mammalian ARC (Kameda et al., 2001).

$\alpha$-Melanocyte stimulating hormone $(\alpha-\mathrm{MSH})$ is synthesized in the pituitary and ARC of mammals, and in the IN of chickens (Gerets et al., 2000). It is derived from its precursor proopiomelanocortin (POMC) through a proteolytic process, together with $\beta$ - and $\gamma$-MSH, adrenocorticotropic hormone (ACTH), and $\beta$-endorphin. $\alpha-\mathrm{MSH}$ potently suppressed food intake through melanocortin receptors (MCRs) of both mammals (Seeley et al., 2004) and neonatal chicks (Kawakami et al., 2000). The relationship between $\mathrm{NE}$ and POMC or $\alpha-\mathrm{MSH}$ is not well known, although it is reported that $\mathrm{NE}$ can affect $\beta$-endorphin, which is also derived from POMC (McCormack et al., 1988).

In the present study two experiments were done to clarify the mechanisms by which intracerebroventricular (ICV) injection of NE reduces food intake in neonatal chicks. Experiment 1 was done to confirm the effect of several doses of ICV injection of NE on food intake and NPY mRNA expression in the CNS following a $3 \mathrm{~h}$ fast followed by refeeding. In Experiment 2 the effect of ICV injection of NE on NPY and POMC mRNA expression under ad libitum feeding conditions was investigated.

\section{Materials and Methods}

\subsection{Animals}

Day-old male layer chicks (Julia) were purchased from a local hatchery (Murata Hatchery, Fukuoka, Japan). The chicks were maintained in a windowless room at $30 \pm 1^{\circ} \mathrm{C}$ with continuous lighting and had free access to a commercial starter diet (Toyohashi Feed and Mills Co. Ltd., Aichi, Japan) and water, unless otherwise mentioned. On the day before the experiment, chicks were distributed into individual cages. They were 3 days old (Experiment 1) and 3 or 4 days old (Experiment 2) with their average body weight between groups being as uniform as possible. Experimental 
procedures followed the guidance for Animal Experiments in Faculty of Agriculture and in the Graduate Course of Kyushu University and the Law (No. 105) and Notification (No. 6) of the Government.

\subsection{Drugs preparation}

The birds were injected $(10 \mu \mathrm{l}) \mathrm{ICV}$ using a microsyringe according to the methods by Davis et al. (1978). NE (bitrate salt) was purchased from Sigma (St. Louis, MO, USA). NE was dissolved in $0.85 \%$ saline containing $0.1 \%$ Evans blue dye on the day of the experiment. At the end of the experiments, birds were sacrificed by decapitation and the location of the injection site confirmed.

\subsection{ICV injection of $N E$}

Birds were fasted $3 \mathrm{~h}$ before injection with free access to water. They were injected ICV with saline containing NE at doses of 0, 25, 50, or $100 \mu \mathrm{g}$ in Experiment 1. Food intake was determined at 30, 60 and 120 min after the injection. In Experiment 2, chicks under ad libitum feeding conditions were given saline or NE (50 $\mu \mathrm{g})$ and then fasted for 15, 30, 60 and $120 \mathrm{~min}$.

\section{4.mRNA expression levels of NPY}

In Experiment 1, at 120 min post-injection, the chicks were sacrificed and the brain stem between stria medullaris and posterior comissure was collected according to Kuenzel and Masson (1988). This brain tissues including the hypothalamus were immediately immersed in RNA later (Sigma, St. Louis, MO, USA), and stored at $-80^{\circ} \mathrm{C}$ after one night immersion at $4{ }^{\circ} \mathrm{C}$. Total cellular RNA was isolated from brain tissues by homogenization in 500-600 $\mu 1$ TRIzol reagent about 40 days after tissue collection. The homogenates were added to $133-160 \mu$ of chloroform after which the mixture was shaken vigorously for $10 \mathrm{sec}$. After a few min the mixture was centrifuged at 12,000 $\times$ $\mathrm{g}$ for $30 \mathrm{~min}$ at $4^{\circ} \mathrm{C}$. The aqueous phase was removed and the RNA was precipitated with isopropanol and collected by centrifugation at $10,000 \times \mathrm{g}$ for $10 \mathrm{~min}$ at $4{ }^{\circ} \mathrm{C}$. The supernatant was discarded and the RNA pellet was washed with $70 \%$ ethanol, and centrifuged at $10,000 \times \mathrm{g}$ for $10 \mathrm{~min}$ at $4^{\circ} \mathrm{C}$. The supernatant was discarded and the 
RNA pellet was solubilized in $100 \mu \mathrm{l}$ of diethylpyrocarbonate (DEPC)-treated water. The quantity of RNA was determined by measuring the absorbance at $260 \mathrm{~nm}$. The RNA was diluted in DEPC-treated water to $0.1 \mathrm{mg} / \mathrm{ml}$ total RNA for all samples. In Experiment 2, chicks were fasted and the brains taken out. At 15, 30, 60, and $120 \mathrm{~min}$ after the injection, the brain samples and RNA were collected similarly as in Experiment

1. The total RNA isolation was done about 2 days after sample collection.

Total RNA was reverse-transcribed to cDNA using PrimeScript RT reagent kit (Takara Bio Inc., Shiga, Japan). The amount of total RNA used was 300 ng (Experiment 1) and $400 \mathrm{ng}$ (Experiment 2). This procedure used Oligo dT primer and random 6 mer.

Real-time PCR analysis was performed with a Line Gene (BioFlux, Co. Ltd., Tokyo Japan) in $10 \mu 1$ optical reaction tubes. Amplification of cDNA (10 ng) was performed using SYBR Premix ExTaq II (Takara Bio Inc, Shiga, Japan) and specific sense and anti-sense primers for NPY, POMC and glyceraldehyde-3-phosphate dehydrogenase (GAPDH, internal standard). The sequences and references of the three primers are shown in the Table. In Experiment 1, the real-time PCR was cycled once at $95^{\circ} \mathrm{C}$ for $10 \mathrm{sec}, 40$ repetitions at $95^{\circ} \mathrm{C}$ for $5 \mathrm{sec}, 60^{\circ} \mathrm{C}$ for $30 \mathrm{sec}$, and fluorescence acquisition at $60^{\circ} \mathrm{C}$. On completion of cycling, amplicons were directly identified using the melting point analysis protocol of the Line Gene instrument $\left(65^{\circ} \mathrm{C}-95^{\circ} \mathrm{C}\right.$; step size $0.5^{\circ} \mathrm{C}$, hold time $30 \mathrm{sec}$ ). Quantitative real-time PCR was performed in duplicate for each sample. The mRNA of NPY was normalized to the GAPDH representation. In Experiment 2, the real-time PCR was cycled almost the same as Experiment 1, except for using 45 times repetitions for NPY, and 35 cycles for GAPDH. The repetition of NPY was necessary, and that for GAPDH were enough for the determination. For POMC it was 45 repetitions at $95^{\circ} \mathrm{C}$ for $5 \mathrm{sec}, 60^{\circ} \mathrm{C}$ for $20 \mathrm{sec}$ and fluorescence acquisition at $60^{\circ} \mathrm{C}$.

\subsection{Statistical analysis}

In Experiment 1, data of food intake were statistically analyzed by repeated measure two-way ANOVA, and comparisons between means were made using the Tukey-Kramer test. NPY mRNA expression was analyzed by one-way ANOVA. In Experiment 2, two-way ANOVA was utilized for both mRNA expressions. All 
statistical analyses were done using a commercially available package (Stat View, Version 5, SAS Institute, Cary, USA, 1998).

\section{Results}

\subsection{Effect of ICV NE on food intake}

The ICV injection of NE significantly inhibited food consumption in fasted chicks when compared with control [Fig. 1, F $(3,30)=12.804, \mathrm{P}<0.0001]$. The anorexic effect of the higher dose of NE (50 and $100 \mu \mathrm{g}$ ) lasted through $120 \mathrm{~min}$. A significant [F $(6,60)=4.290 \mathrm{P}=0.0012]$ interaction between time and $\mathrm{NE}$ was detected, indicating that the effect of ICV NE diminished with time.

\subsection{Effect of ICV NE on NPY and POMC mRNA levels in chick brain}

As shown in Figs 2 and 3, NPY mRNA levels were not different until 120 min after injection of $\mathrm{NE}$ under both fasting $[\mathrm{F}(3,29)=2.498, \mathrm{P}=0.0794]$ (Experiment 1) and feeding conditions $[\mathrm{F}(1,59)=0.009, \mathrm{P}=0.9256]$ (Experiment 2$)$. POMC mRNA levels were not different between the control and NE-treated group until 120 min after injection of NE [F $(1,48)=6.506 e-7, P=0.9994]$ (Experiment 2, Fig 4).

\section{Discussion}

In Experiment 1, food intake was decreased dose-dependently after ICV injection of NE (Fig. 1). Chicks administered higher doses of NE crouched and appeared asleep. This was consistent with a previous report of NE-induced narcolepsy (sleep-like behavior) (Bungo et al., 2001). Narcolepsy induced soon after injection was the apparent reason for decreased food intake, as was previously seen in broiler chicks (Bungo et al., 2001) and young adult Leghorn chickens (Denbow et al., 1983). The doses of NE used in the present study were far higher than the normal content in chick brain (Saito et al., 2004). The narcoleptic effect induced by NE masked any feeding stimulatory effect previously observed with lower doses (Bungo et al., 1999, 2001; Denbow et al., 1993). Bungo et al. (1999) reported that high dose (250 ng) of clonidine caused narcolepsy effect. Therefore, the doses used in this study $(25,50$, and $100 \mu \mathrm{g})$ were enough to induce narcolepsy, probably acting through $\alpha_{2}$-adrenoceptors, 
instead of feeding. In the study of Steinman et al., (1987) chicks administered lower NE doses than used in the present study showed narcolepsy, even though they consumed as much food as the control group. As the dosage increased near that of this study, the time they spent in a sleep-like posture increased.

The NE doses used here were the same as the previous report (Bungo et al., 2001). The dose was pharmacological, but not physiological level. On clarifying a more detailed mechanism of this anorectic effect of high NE, we focused on a report saying that this depression of behavior was observed 2 day-old leghorn chicks after administered NPY (Steinman et al., 1987). Therefore, we expected that the feeding-suppressing effect of NE may be involved in the effect of NPY. In addition, the reduction of food intake was possibly regulated by an anorexigenic factor. So we decided to investigate the mRNA expression of POMC, the precursor of a potent anorexigenic peptide.

There were no significant differences in NPY mRNA expression in the brain stem between NE and control groups in either Experiment 1 or 2 (Figs. 2 and 3). Therefore, there appears to be no relationship between the decrease in food intake caused by NE injection and NPY synthesis, since no change was seen in NPY mRNA 30, 60, and 120 min after injection when the food intake was less than that of the control. However, the effect of NE on feeding behavior is highly dependent on the sites and receptors where NE acts, even within the hypothalamus in mammals (Wellman, 2000). Similarly, in chickens NE has different effects on food intake dependent on the injection sites (Denbow et al., 1993). Furthermore, NPY mRNA expression is influenced by the feeding situation, especially in the IN (Kameda et al., 2001). In this study, the whole brain stem was analyzed including not only the IN, but also the PVN and LHA, where NE has opposite effects on food intake. NPY mRNA is abundant in the whole brain (Wang et al., 2000) and the up and down of the gene expression in the individual nucleus was masked by using the brain stem. It was difficult to detect whether NPY mRNA expression was influenced by NE injection by this method. If the brain tissues were analyzed by the nucleus of hypothalamus, there may be a difference of NE injection.

Another reason for the difficulty of detecting the interaction of NE and NPY was its 
complex nature. While it is known that NE and NPY are colocalized in the CNS (Everitt et al., 1984), further research is needed to clarify the physiological effects of their interaction. NPY is reported to have some effect on NE through $\alpha_{2}$-adrenergic receptors (Illes et al., 1990). NPY decreased NE or its metabolite overflow in the rat hypothalamus and medulla in vitro (Hastings et al., 2001, 2004, Bitran et al., 1999), whereas the same neurotransmitter caused an increase in vivo (Myers et al., 1996, Pavia et al., 1995). Moreover, stimulation of NPY $\mathrm{Y}_{1}$ receptors increased NE in vivo (Hastings et al., 1997). In addition, reduced NE led to increased NPY mRNA levels (Kalra et al., 1997). Activation of $\alpha_{2}$-adrenergic receptors reduced NPY immunoreactivity in the rat cortex (Chang et al., 1996).

There was no significant difference in POMC mRNA expression between the NE-treated and control groups, indicating that there was no relationship between NE-induced anorexia and $\alpha$-MSH synthesis (Fig. 4). This unchanged expression can be masked by the analyzing the whole tissue similarly as NPY genes. Although POMC mRNA expression changed with time, this decrease may be caused by another factor because its expression in the IN is not sensitive to energy shortage (Boswell, 2005). It decreased through $60 \mathrm{~min}$ post-injection, then increased $120 \mathrm{~min}$ after injection. One possible reason may be that POMC can be processed to $\beta$-endorphin and ACTH, which can be mediators of feeding behavior of chicks (McCormack et al., 1988). In the CNS of chickens, $\alpha$-MSH and $\beta$-endorphin are observed in the IN (Boswell, 2005), and like in mammals, the POMC peptide is mainly metabolized to $\alpha$-MSH and inactive $\beta$-endorphin in the ARC.

The interaction of $\alpha-\mathrm{MSH}$ and monoamines such as dopamine and serotonin, has not been well studied (Gonzalez et al., 1996). While the relationship between central $\mathrm{NE}$ and $\alpha-\mathrm{MSH}$ or the melanocortin system on sexual behavior has been investigated (Scimonelli et al., 2000), their role in energy balance regulation is lacking.

In conclusion, ICV NE did not influence the mRNA expression of NPY or POMC in the whole brain stem. Although a possibility of their interaction in neonatal chicks still exists. An antagonist of the $\alpha_{2}$ adrenoceptors attenuated the feeding stimulation effect of NPY (Tachibana et al., 2009). The relationship between central NE and peptides mRNA expression should be analyzed by detailed nuclei of the hypothalamus. 


\section{References}

Bai, F.L., Yamano, M., Shiotani, Y., Emson, P.C., Smith, A.D., Powell, J.F., Tohyama, M. (1984) An arcuato-paraventricular and -dorsomedial hypothalamic neuropeptide Y-containing system which lacks noradrenaline in the rat. Brain Res. 331: 172-175

Bitran, M., Tapia, W., Eugenin, E., Orio, P., Boric, M.P. (1999) Neuropeptide Y induced inhibition of noradrenaline release in rat hypothalamus: role of receptor subtype and nitric oxide. Brain Res. 851: 87-93

Bungo, T., Shimojo, M., Masuda, Y., Choi, Y-H., Denbow, D.M., Furuse, M. (1999) Induction of food intake by a noradrenergic system using clonidine and fusaric acid in the neonatal chick. Brain Res. 826: 313-316

Bungo, T., Kawakami, S-I., Ohgushi, A., Sashihara, K., Saito, N., Sugahara, K., Hasegawa, S., Denbow, D.M., Furuse, M. (2001) Intracerebroventricular injection of fusaric acid attenuates the anorexia by glucagon-like peptide 1 in the neonatal chick. Pharmacol. Biochem. Behav. 70: 251-255

Boswell, T. (2005) Regulation of Energy Balance in Birds by the Neuroendocrine Hypothalamus. J Poult Sci 42: 161-181

Chang, T.K., Niu, C.S., Cheng, J.T. (1996) Activation of al-adrenoceptors to lower cerebrocortical neuropeptide Y (NPY)-like immunoreactivity in rats receiving pargyline treatment. Neurosci. Lett. 218: 161-164

Davis, J.L., Masuoka, D.T., Gerbrandt, L.K., Cherkin, A. (1978) Autoradiographic distribution of L-Proline in chicks after intracerebral injection. Physiol. Behav. 22: 693-695

Denbow, D.M., Van Krey, H.P., Lacy, M.P., Dietrick, T.J. (1983) Feeding, drinking and body temperature of Leghorn chicks: effects of ICV injections of biogenic amines. Physiol. Behav. 31: 85-90

Denbow, D.M., Sheppard, B.J. (1993) Food and water intake responses of the domestic fowl to norepinephrine infusion at circumscribed neural sites. Brain Res. Bull. 31:121-128

Everitt, B.J., Hökfelt, T., Terenius, L., Tatemoto, K., Mutt, V., Goldstein, M. (1984) Differential co-existence of neuropeptide Y (NPY)-like immunoreactivity with catecholamines in the central nervous system of the rat. Neuroscience 11:443-462

Gerets, HHJ., Peeters, K., Arckens, L., Vandesande, F., Berghman, LR. (2000) Sequence and distribution of pro-opiomelanocortin in the pituitary and the brain of the chicken (Gallus gallus). J. Comp. Neurol. 417: 250-262

Gonzalez, MI., Kalia, V., Hole, DR., Wilson, CA. (1996) a-Melanocyto-stimulating hormone $(\alpha-\mathrm{MSH})$, and melanin-concentrating hormone $(\mathrm{MCH})$ modify monoaminergic levels in the pre-optic area of the rat. Peptides 18: 387-92

Hastings, J.A., Pavia, J.M., Morris, M.J. (1997) Neuropeptide Y and [Leu31,Pro34] 
neuropeptide $\mathrm{Y}$ potentiate potassium-induced noradrenaline release in the paraventricular nucleus of the aged rat. Brain Res. 750: 301-304

Hastings, J.A., McClure-Sharp, J.M., Morris, M.J. (2001) NPY Y1 receptors exert opposite effects on corticotropin releasing factor and noradrenaline overflow from the rat hypothalamus in vitro. Brain Res. 890: 32-37

Hastings, J.A., Morris, M.J., Lambert, G., Lambert, E., Esler, M. (2004) NPY and NPY Y1 receptor effects on noradrenaline overflow from the rat brain in vitro. Regul. Pept. 120: 107-112

Illes, P., Regenold, J.T. (1990) Interaction between neuropeptide Y and noradrenaline on central catecholamine neurons. Nature 344: 62-63

Kalra, PS. (1997) Appetite and body weight regulation: is it all in the brain? Neuron 19:227-230

Kalra, P.S., Dube, M.G., Xu, B., Farmerie, W.G., Kalra, S.P. (1997) Evidence that dark-phase hyperphagia induced by neurotoxin 6-hydroxydopamine may be due to decreased leptin and increased neuropeptide Y signaling. Physiol. Behav. 63: 829-835

Kameda, Y., Miura, M., Nishimaki, T. (2001) Localization of neuropeptide Y mRNA and peptide in the chicken hypothalamus and their alterations after food deprivation, dehydration, and castration. J. Comp. Neurol. 436: 376-388

Kawakami, S-I., Bungo, T., Ando, R., Ohgushi, A., Shimojo, M., Masuda, Y., Furuse, M. (2000) Central injection of $\alpha$-melanocyte stimulating hormone inhibits fasting- and neuropeptide Y- induced feeding in neonatal chicks. Eur. J. Pharmacol. , 398: 361-364

Kuenzel, W.J. and Masson, M. (1978) A stereotaxic atlas of the brain of the chick (Gallus domesticus). The Johns Hopkins University Press.

Kuenzel, W.J., Douglass, L.W., Davison, B.A. (1987) Robust feeding following central administration of neuropeptide Y or peptide YY in Chicks, Gallus domesticus. Peptides 8: 823-828

Leibowitz, S.F. (1977) Paraventricular nucleus: A primary site mediating adrenergic stimulation of feeding and drinking. Pharmacol. Biochem. Behav. 8: 163-175

Leibowitz, S.F. (1988) Hypothalamic paraventricular nucleus: interaction between $\alpha$ 2-noradrenergic system and circulating hormones and nutrients in relation to energy balance. Neurosci Biobehav Rev 12: 101-109

Leonard, B.E., Kafoe, W.F., Thody, A.J., Shuster, S. (1976) The effect of $\alpha$-melanocyte stimulating hormone $(\alpha-\mathrm{MSH})$ on the metabolism of biogenic amines in the rat brain. J.

Neurosci. Res. 2: 39-45

Mallick, B.N., Singh, S., Pal, D. (2005) Role of alpha and beta adrenoceptors in locus coeruleus stimulation-induced reduction in rapid eye movement sleep in freely moving rats. Behav. Brain Res. 158: 9-21

McCormack, J.F., Denbow, D.M. (1988) Feeding, drinking and temperature response to intracerebroventricular $\beta$-endorphin in the domestic fowl. Peptides 9: 709-715 
Morien, A., McMahon, L., Wellman, P.J. (1993) Effects on food and water intake of the $\alpha 1$-adrenoceptor agonists amidpherine and SK\&F-89748. Life Sci. 53: 169-174

Myers, R.D., Lankford, M.F., Roscoe, A.K. (1996) Neuropeptide Y perfused in the preoptic area of rats shifts extracellular efflux of dopamine, norepinephrine and serotonin during hypothermia and feeding. Neurochem. Res. 21: 637-648

Pavia, J.M., Hastings, J.A., Morris, M.J. (1995) Neuropeptide Y potentiation of potassium-induced noradrenaline release in the hypothalamic paraventricular nucleus of the rat in vivo. Brain Res. 690: 108-111

Saito, E-S., Kaiya, H., Tachibana, T., Tomonaga, S., Denbow, D.M., Kangawa, K., Furuse, M. (2005) Inhibitory effect of ghrelin on food intake is mediated by the corticotropin-releasing factor system in neonatal chicks. Regul. Pept. 125: 201-208

Saito, S., Takagi, T., Koutoku, T., Saito, E-S., Hirakawa, H., Tomonaga, S., Tachibana, T., Denbow, D.M., Furuse, M. (2004) Differences in catecholamine metabolism and behaviour in neonatal broiler and layer chicks. Br. Poult. Sci. 45: 158-162

Scimonelli, T., Medina, F., Wilson, C., Celis, ME. (2000) Interaction of $\alpha$-melanotropin $(\alpha-\mathrm{MSH})$ and noradrenaline in the median eminence in the control of female sexual behavior. Peptides 21: 219-223

Seeley, RJ., Drazen, DL., Clegg, DJ, (2004) The critical role of the melanocortin system in the control of energy balance. Annu. Rev. Nutr. 24: 133-49

Shiraishi, J-i., Yanagita. K., Fujita, M., Bungo, T, (2007) Central insulin suppresses feeding behavior via melanocortins in chicks. Domest. Anim. Endocrinol. 34: 223-228

Steinman, J.L., Fujikawa, D.G., Wasterlain, C.G., Cherkin, A., Morley, J.E. (1987) The effects of adrenergic, opioid and pancreatic polypeptidergic compounds on feeding and other behaviors in neonatal leghorn chicks. Peptides 8: 585-592

Tachibana, T., Tazawa, M., Sugahara, K. (2001) Feeding increases 5-hydroxytryptamine and norepinephrine within the hypothalamus of chicks. Comp. Biochem. Physiol. A 130:715-722

Tachibana, T., Sugahara, K., Ueda, H., Cline, M. (2009) Role of adrenergic alpha-2-receptors on feeding behavior in layer-type chicks. General and Comp. Endocrinol. 161: $407-411$

Tatemoto, K., Carlquist, M., Mutt, V. (1982a) Neuropeptide Y-a novel brain peptide with structural similarities to Peptide YY and pancreatic polypeptide. Nature 296: 659-660

Tatemoto, K. (1982b) Neuropeptide Y: Complete amino acid sequence of the brain peptide. Proc. Natl. Acad. Sci. U.S.A. 79: 5485-5489

Wang, X., Day, J.R., Vasilatos-Younken, R. (2001) The distribution of neuropeptide Y gene expression in the chicken brain. Mol. Cell. Endocrinol. 174: 129-136

Wellman, P.J. (2000) Norepinephrine and the control of food intake. Nutrition 16:837-842

Zhang, R., Tachibana、T., Takagi, T., Koutoku, T., Denbow, D.M., Furuse, M. (2003) Centrally administered norepinephrine modifies the behavior induced by corticotropin-releasing 


\section{Legends of Figures}

Fig. 1. Food intake of fasted chicks following ICV injection of $\mathrm{NE}(0,25,50,100 \mu \mathrm{g})$. Food intake was measured at 30,60 and 120 min after administration. Results were shown by means \pm SEM. Data was analyzed by two-way ANOVA and then Tukey-Kramer test. Groups with different letters are significantly different $(\mathrm{P}<0.05)$. The number of chicks used in each group was control, 9; NE $25 \mathrm{mg}$, 9; NE $50 \mathrm{mg}, 8$; and NE $100 \mathrm{mg}, 8$.

Fig. 2. NPY mRNA expression following ICV injection of NE $(0,25,50,100 \mu \mathrm{g})$ fasted chicks $2 \mathrm{~h}$ after refeeding. NPY mRNA was measured $120 \mathrm{~min}$ after administration. Results were shown by means \pm SEM. Data was analyzed by one-way ANOVA. The number of chicks used in each group was control, 9; NE $25 \mathrm{mg}$, 8; NE $50 \mathrm{mg}$, 8; and NE $100 \mathrm{mg}, 8$.

Fig. 3. NPY mRNA expression of chicks fed ad libitum following ICV of NE (0 or $50 \mu \mathrm{g})$. Results were shown by means \pm SEM. Data was analyzed by two-way ANOVA. The number of chicks used was as follows: 15 min control, 10; 15 min NE, 6; 30 min control, 8; 30 min NE, 9; 60 min control, 8; 60 min NE, 9; 120 min control, 9; 120 min NE, 8, respectively.

Fig. 4. POMC mRNA expression expression of chicks fed ad libitum following ICV of NE $(0$ or $50 \mu \mathrm{g}$ ). Results were shown by means \pm SEM. Data was analyzed by two-way ANOVA. The number of chicks used was as follows: 15 min control, 9; 15 min NE, 7; 30 min control, 7; 30 min NE, 7; 60 min control, 7; 60 min NE, 6; 120 min control, 6; 120 min NE, 7, respectively. 


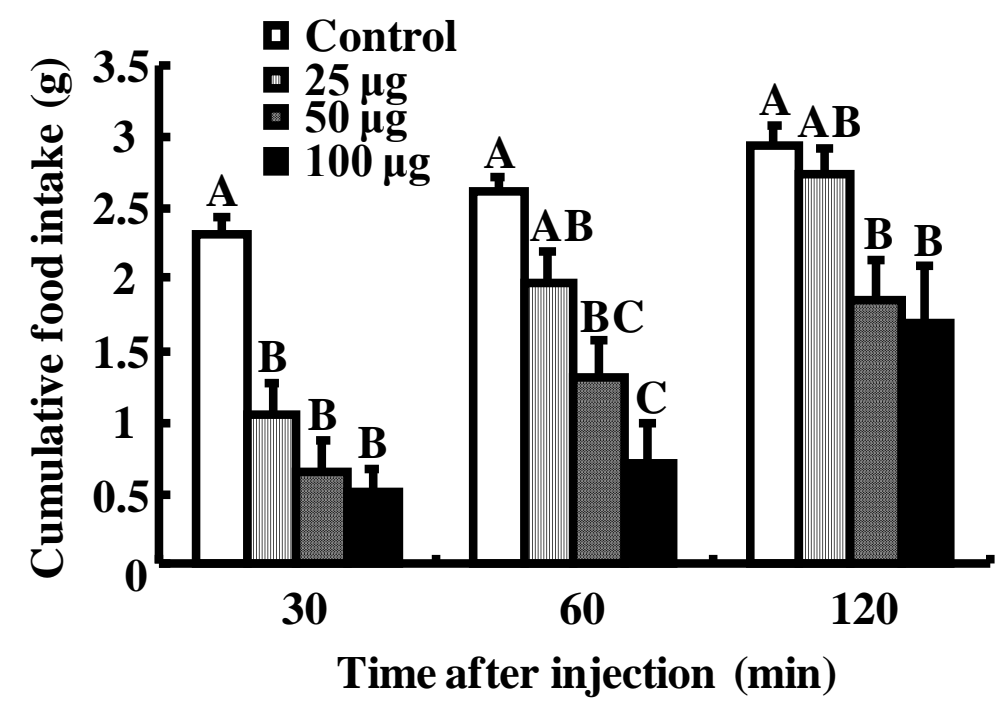

Fig. 1 


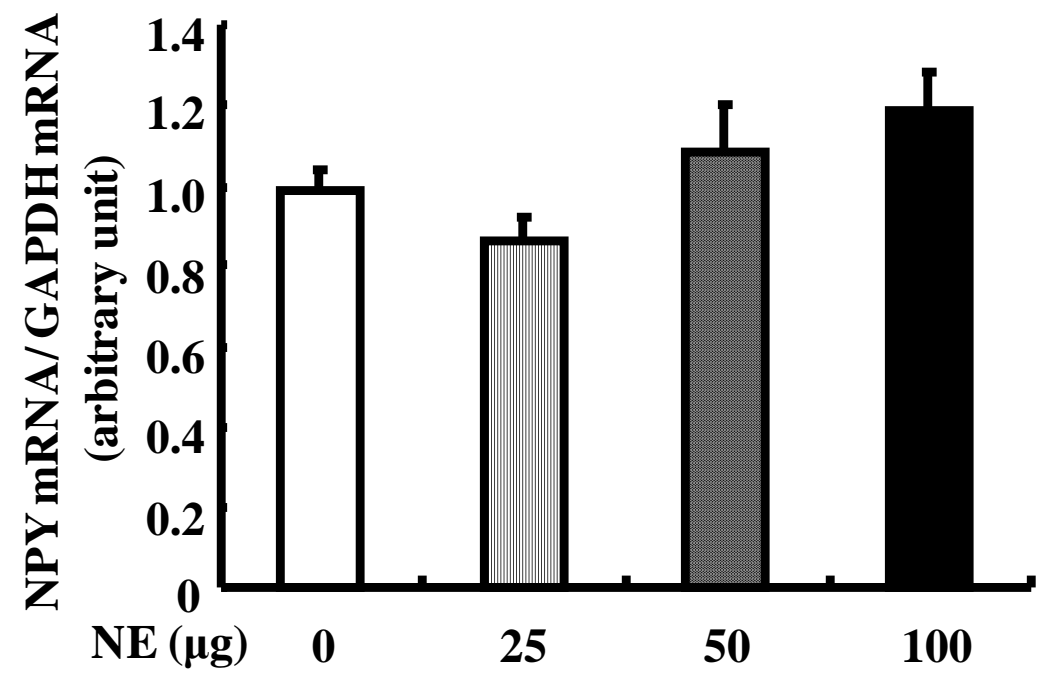

Fig. 2 


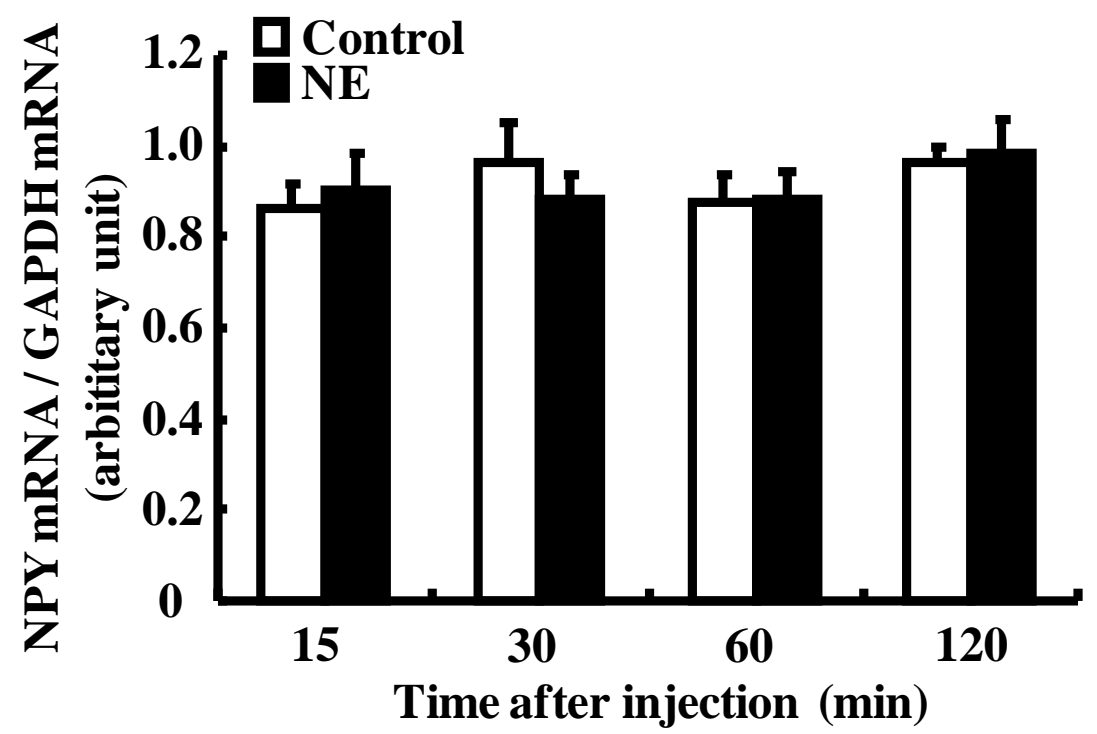

Fig. 3 


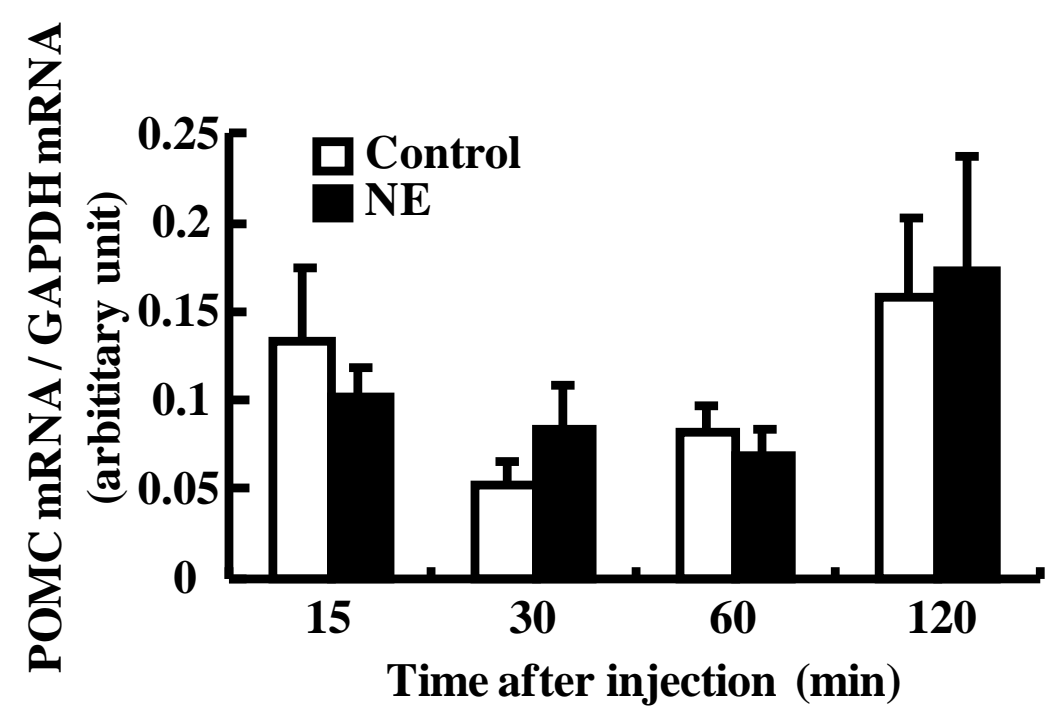

Fig. 4 
Table. The sequence of primers

\begin{tabular}{|c|c|c|}
\hline Gene & $\begin{array}{c}\text { sense } \\
\text { antisense }\end{array}$ & reference \\
\hline NPY & $\begin{array}{l}5^{\prime}-\text { ggc act aca tca acc tca tc-3' } \\
5^{\prime}-\text { ctg tgc ttt ccc tca aca ag-3' }\end{array}$ & Saito et al., 2005 \\
\hline POMC & $\begin{array}{l}5^{\prime} \text {-aac agc aag tgc cag gac c-3' } \\
5^{\prime} \text {-atc acg tac ttg cgg atg c-3' }\end{array}$ & Shiraishi et al., 2007 \\
\hline GAPDH & $\begin{array}{l}5^{\prime} \text {-gtg gag aga tgg cag agg tg-3' } \\
5^{\prime} \text {-gca ggt cag gtc aac aac ag-3' }\end{array}$ & primer 3 (http://frodo.wi.mit.edu) \\
\hline
\end{tabular}

The sequences and references used are shown. The sequence of the primers of GAPDH was determined consulting primer 3 . 